Chaturachinda, K. (1972). American fournal of Obstetrics and Gynecology,

El-Mahgoub, S., Karim, M., and Ammar, R. (1972). Acta Obstetrica and Gynecologica Scandinavica, 51, 251.

Emens, J. M., Jordan, J. A., and McLaren, H. C. (1973). British Medical fournal, $2,421$.

Jeppson, S. (1972). Acta Obs.etricia and Gynecologica Scandinavica, 51, 257. Jones, J. R., and Lonky, S. (1971). New York State Journal of Medicine, 71,
2279.
Karim, M., et al. (1971). British Medical fournal, 1, 200.

Liston, W. A., Bradford, W. P., Downie, J., and Kerr, M. G. (1970). Lancet, 1, 382.

Mowat, J. (1974). Ob-Gyn Digest. In press.

Mowat, J. (1974). Ob-Gyn Digest. In press.
Powell, L. S., and Seymour, R. J. (1971). American fournal of Obstetrics and Gynecology, 110, 36.

Steptoe, P. C. (1967). Laparoscopy in Gynaecology. Edinburgh, Livingstone.

\title{
Surgical Reduction of Tumour Bulk in Management of Abdominal Burkitt's Lymphoma
}

\author{
I. T. MAGRATH， S. LWANGA，W. CARSWELL， N. HARRISON
}

British Medical fournal, 1974, 2, 308-312

\section{Summary}

The results of a retrospective study of the value of reductive surgery in the treatment of abdominal Burkitt's lymphoma are reported. Nine patients had almost complete removal of the tumour, 16 had little over half of the tumour removed, and 43 underwent biopsy only. All patients subsequently received chemotherapy. There was a highly significant difference in the proportion of patients achieving a sustained durable remission $(P>0.0001)$ and a significant difference in survival $(P>0.05)$ between the group having almost complete removal and the partial resection group. Partial resection gave no advantage over no surgery. We believe that whenever possible complete removal of the abdominal tumour should be attempted regardless of the presence of extra-abdominal tumour; but unless at least $90 \%$ of the tumour can be removed there is no advantage in partial resection in terms of response to subsequent chemotherapy. In particular the removal of one of two involved ovaries can no longer be recommended. The implications of these results are related to cancer treatment strategy.

\section{Introduction}

Burkitt's lymphoma is an exceptional tumour in many respects, not least of which is its dramatic response to chemotherapy. Some $80 \%$ of all patients admitted to the Lymphoma Treatment Centre, Kampala, achieve complete clinical remission after chemotherapy (Ziegler, 1972), and though about twothirds of these relapse the overall predioted long-term survival rate based on 185 patients treated at the centre between 1967 and 1972 is 57\% (Magrath and Ziegler, 1973). The relapse and survival rates depend largely on whether abdominal tumour is present. Where there is only extraabdominal tumour, regardless of site, cumulative long-term

\section{Lymphoma Treatment Centre, Kampala, Uganda}

I. T. MAGRATH, M.B., M.R.C.P., Director (Present address: Department of Pediatric Oncology, National Cancer Institute, Bethesda, Maryland 20014, U.S.A.)

Makerere University, Kampala, Uganda

S. LWANGA, B.sc., Medical Statistician

Mulago Hospital, Kampala, Uganda

W. CARSWELL, M.B., F.R.C.S., Senior Surgical Registra

N. HARRISON, M.D., F.R.C.S., Senior Surgical Registrar (Present address: Institute of Urology, St. Peter's and St. Paul's Hospitals, London) survival is $82 \%$, whereas with abdominal tumour (not extensively resected surgically) it ranges from $29 \%$ to $52 \%$ depending on the presence and site of extra-abdominal tumour (table I). This finding raises the question whether complete or nearly complete resection of abdominal tumour, when possible, would improve the response to chemotherapy in terms of relapse and survival. Since $39 \%$ of male patients and $73 \%$ of female patients with Burkitt's lymphoma have abdominal involvement, and since ovarian tumour, which is readily resected, accounts for over half of the abdominal tumours in female patients (Magrath, 1974 a), this is an important consideration.

TABLE I-Clinical Staging of Burkitt's Lymphoma and Relation to Prognosis. Results were Calculated Actuarially (see Text)

\begin{tabular}{l|c|c|c}
\hline Stage A & Extent of Tumour & $\begin{array}{c}\text { Survival Rate } \\
(100 \text { Weeks or } \\
\text { More) }\end{array}$ & $\begin{array}{c}\text { Remission Rate* } \\
\text { (50 Weeks or } \\
\text { More) }\end{array}$ \\
\hline Stage B & $\begin{array}{c}\text { Single tumour } \\
\text { outside } \\
\text { abdomen } \\
\text { Multiple extra- } \\
\text { abdominal } \\
\text { tumours (inclu- } \\
\text { ding nervous } \\
\text { system) } \\
\text { Abdominal } \\
\text { tumour with } \\
\text { or without facial } \\
\text { tumour } \\
\text { Abdominal } \\
\text { tumour with } \\
\text { tumour at other } \\
\text { sites (except } \\
\text { face alone) }\end{array}$ & $82 \%$ & $61 \%$ \\
\hline
\end{tabular}

*Remission rate represents proportion of patients who have not relapsed.

Previously chemotherapy has been used as an adjunot to surgery, putatively to prevent the development of metastases (Nora and Preston, 1963; Fisher, 1972). This mode of utilization, however, has met with little success (Wolff et al., 1968; Fisher, 1972), and in multicentric tumours or tumours which are potentially widely disemminated from the outset-for example, the lymphomas-a radically different approach has been necessary. In these cases there has been a reversal of roles, with surgery in effect being used as a relatively minor adjunct to chemotherapy. In the treatment of abdominal Burkitt's lymphoma surgery has possibly a much more important place, and in this paper we attempt to evaluate the potential advantages of a combined surgical and chemotherapeutic approach and in particular to determine the importance of the extent of surgical resection of tumour bulk. Since radiotherapy is unavailable in Uganda it played no part in the treatment of these patients. 


\section{Patients and Methods}

All patients admitted to the Lymphoma Treatment Centre during August 1967 to August 1972 with cytologically or histologically proved Burkitt's lymphoma and treated by chemotherapy were subjected to analysis. Only surgery of the initial tumour was considered, and its effectiveness is therefore probably best judged on the unmaintained sustained remission rate-that is, the proportion of patients who achieve complete remission and never relapse. Prolonged, tumour-free survival (in effect, cure) is, of course, the ultimate aim of therapy, and we therefore also assessed the value of surgery in terms of survival rate, a measurement which, however, is dependent also on the efficacy of relapse treatment.

Comparison of groups of patients subjected to extensive or pantial resection or not operated on was based on actuarial prediction of complete remission and survival rates at 50 and 100 weeks respectively (referred to here simply as remission and survival rates), for at these points the actuarial curves become horizontal and relapse or tumour-related death thereafter is very unlikely (Ziegler et al., 1972 a). The $\chi^{2}$ test was used to assess the statistical significance of differences between the groups, taking account of the sum of the individual follow-up periods of the patients in each group.

Extent of Surgical Resection.-Patients with intraabdominal tumours presented at a variety of hospitals in Uganda. In most cases they were referred at once to the Lymphoma Treatment Centre. Some, however, underwent laparotomy at the referring hospital before being transferred. At the centre all patients who were fit enough were subjected to laparotomy, and whenever possible extensive surgical reduotion of tumour bulk was attempted, since it has been suggested that this is of value (Morrow et al., 1967). Whether this was achieved, however, depended in part on the organs involved. Mesenteric, bowel, and splenic masses were usually amenable to total resection. On the other hand, when both kidneys or a large part of the liver were involved or the tumour was arising from retroperitoneal tissues only partial resection could be achieved. In the case of bilateral ovarian involvement the policy at the centre was to remove only one ovary, thus, hopefully, to achieve reduction in tumour bulk without sterilizing the patient and necessitating replacement hormonal therapy. At up-country hospitals, however, bilateral ovarian tumour was removed completely. These patients, therefore, are worthy of particular consideration; since the operative procedure depended on whether surgery was performed in the referring hospital or at the centre it was in effeot decided at random. In addition the sites and extent of the tumours were closely comparable whether one or both ovaries were removed. Patients who were not operated on were in general unfit for surgery, usually because of more extensive tumour. This group therefore had potentially a worse prognosis than the others.

Allocation to Groups.-Altogether 190 patients with Burkitt's lymphoma were admirted to the Lymphoma Treatment Centre during the five-year period. Of these, 91 (48\%) had tumour involving intra-abdominal organs and 41 were subjected to laparotomy (table II). Details of tumour sites, operative procedure, chemotherapy, and relapse and survival were extraoted from the records and the patients were divided into three groups according to the extent (if any) of surgical reduction. Those who had had at least $50 \%$ but less than $90 \%$ of the tumour removed-for example, the largest of two involved ovaries-were allocated to the "partial resection" group (16 cases); in most of these patients little more than half of the tumour was excised. Patients who had had almost all of the tumour removed-both affected ovaries, for example (performed only at the referring hospital), or a mesenteric mass-were designated "extensive resection group" (9 cases); these patients had had at least $90 \%$ of their tumour removed, and often all the visible tumour (prob- ably $99 \%$ or more). Where only biopsy was performed at laparotomy (3 cases) or laparotomy was not performed (40 cases) the patient was allocated to the "non-surgical group" (43 cases). In five cases there was no indication of the amount of tumour removed at operation, and these were excluded from the analysis. A further 14 patients were excluded from the calculations of remission rate and survival because they had died within two weeks of presentation (11 would have been in the non-surgical group and 3 in the partial resection group), and three others were excluded because they could not be followed up (two with extensive resection and one with partial resection).

TABLE II-Data on Patients who had Laparotomy

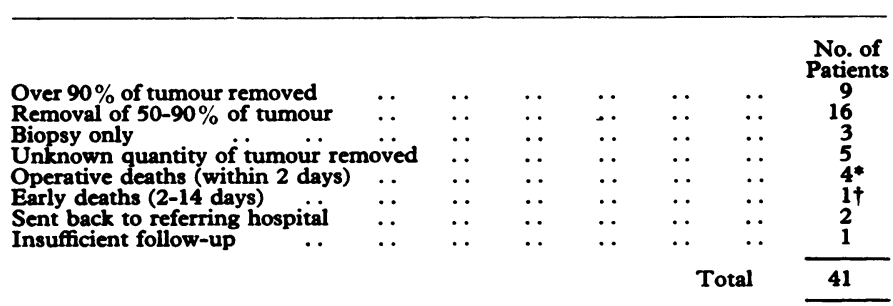

* Three of these patients had partial tumour resection (one of whom died before recovery from the anaesthetic) and one had biopsy only. A further patient, not included here, died during the induction of anaesthesia.

tThis patient had biopsy only.

Chemotherapy.-On the day of surgery or as soon as the diagnosis had been made all patients were given a single dose of cyclophosphamide (40 mg/kg intravenously) then entered into a controlled therapeutic trial designed to compare the efficacy of this alone with that of six doses of cyclophosphamide (Ziegler et al., 1970) or the latter with that of a combination of drugs known as TRIKE (Ziegler et al., 1972 b). Remission and survival rates were similar whichever form of therapy was used (Ziegler, 1972). Patients with meningeal tumour infiltration were treated with intrathecally administered drugs (Ziegler and Bluming, 1971).

\section{Results}

Actuarially predicted remission and survival rates (figs. 1 and 2) showed a clear advantage in patients who had undergone extensive surgical reduotion of tumour $(56 \%$ and $89 \%$ respectively) compared with those who had had only pantial

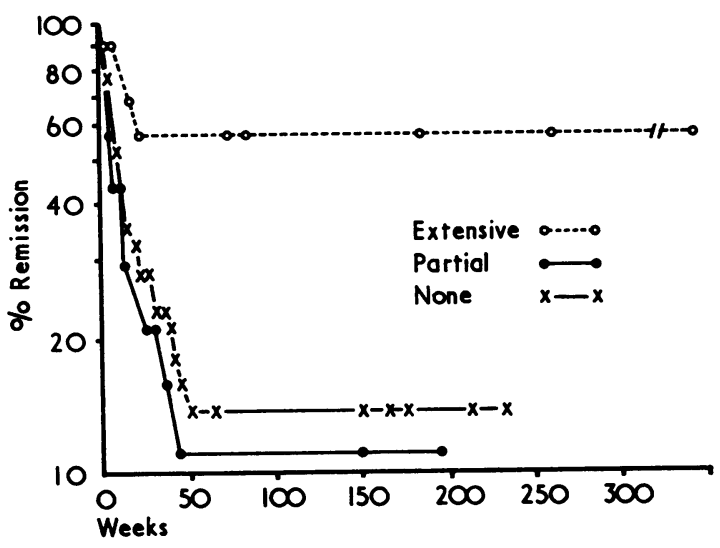

FIG. 1-Actuarial curves of complete remission rates-that is, patients who are completely free from tumour and have not relapsed. After initial chemotherapy no further treatment was given unless patient relapsed. Points on lower two curves before 15 weeks represent several patients (up to 11), but thereafier and on upper curve each point corresponds to single patient. Some of these patients had one or more relapses and appear on pre-plateau part of curves. Others never relapsed. 
TABLE III-Statistical Comparison of the Three Groups of Patients

\begin{tabular}{|c|c|c|c|c|c|c|c|c|c|c|c|c|c|}
\hline \multirow[t]{2}{*}{ Group } & \multirow{2}{*}{$\begin{array}{c}\text { No. of } \\
\text { Patients }\end{array}$} & \multirow{2}{*}{$\underset{\text { Rate }}{\text { Survival }}$} & \multicolumn{2}{|c|}{ No. of Deaths } & \multirow{2}{*}{$\begin{array}{c}\text { Total } \\
\text { Patient- } \\
\text { Weeks of } \\
\text { Survival* }\end{array}$} & \multirow[t]{2}{*}{$x^{2}$} & \multirow[t]{2}{*}{$\mathbf{P}$} & \multirow{2}{*}{$\begin{array}{c}\text { Remission } \\
\text { Rate }\end{array}$} & \multicolumn{2}{|c|}{ No. of Relapses $\ddagger$} & \multirow{2}{*}{$\begin{array}{c}\text { Total } \\
\text { Patient- } \\
\text { Weeks of } \\
\text { Remission § }\end{array}$} & \multirow[t]{2}{*}{$x^{2}$} & \multirow[t]{2}{*}{$\mathbf{P}$} \\
\hline & & & Observed & Expected & & & & & Observed & Expected & & & \\
\hline $\begin{array}{l}\text { Extensive } \\
\text { Partial } \\
\text { Partial } \\
\text { None } \\
\text { Extensive } \\
\text { None }\end{array}$ & $\begin{array}{r}9 \\
16 \\
16 \\
43 \\
9 \\
43\end{array}$ & $\begin{array}{l}89 \% \\
45 \% \\
45 \% \\
37 \% \\
89 \% \\
37 \%\end{array}$ & $\begin{array}{r}1 \\
8 \\
8 \\
26 \\
1 \\
26\end{array}$ & $\begin{array}{r}4 \cdot 7 \\
4.3 \\
10 \cdot 1 \\
23.9 \\
7.5 \\
18 \cdot 5\end{array}$ & $\begin{array}{l}1,564 \\
1,438 \\
1,438 \\
3,400 \\
1,564 \\
3,400\end{array}$ & $\left\{\begin{array}{l}4.5 \\
0.36 \\
8.4\end{array}\right.$ & $\left.\begin{array}{l}<0.05 \\
>0.5 \dagger \\
<0.005\end{array}\right\}$ & $\begin{array}{l}56 \% \\
11 \% \\
11 \% \\
14 \% \\
56 \% \\
14 \%\end{array}$ & $\begin{array}{r}4 \\
14 \\
14 \\
37 \\
4 \\
37\end{array}$ & \begin{tabular}{r|}
$12 \cdot 4$ \\
$5 \cdot 6$ \\
$13 \cdot 2$ \\
$37 \cdot 8$ \\
$18 \cdot 0$ \\
$23 \cdot 0$
\end{tabular} & $\begin{array}{r}1,142 \\
513 \\
513 \\
1,464 \\
1,142 \\
1,464\end{array}$ & $\left\{\begin{array}{l}16.3 \\
0.007 \\
17.9\end{array}\right.$ & $\begin{array}{l}<0.0001 \\
>0.95 t \\
<0.0001\end{array}$ \\
\hline
\end{tabular}

*Sum of individual follow-up periods-either until death or until date last seen alive.

† Nhis includes patients who never achieved complete remission and those who relapsed after period of complete remission.

$\S$ Sum of individual periods of complete remission dated from start of treatment.

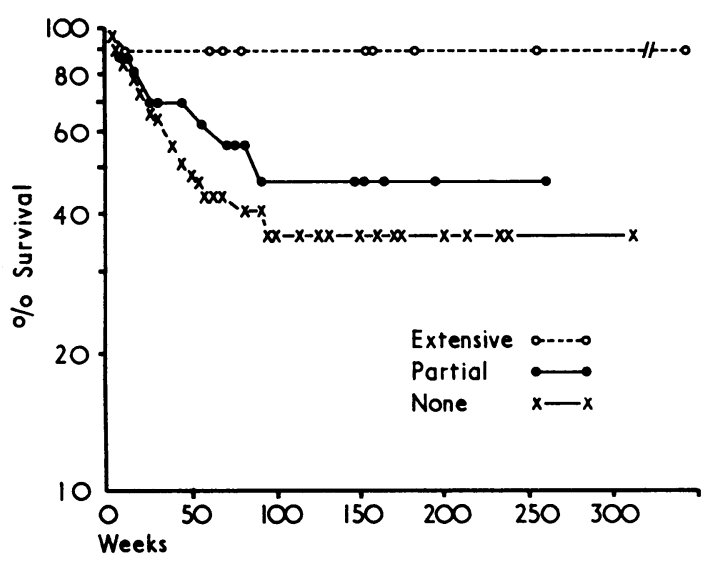

FIG. 2-Actuarial curves of survival of patients having extensive, partial, or no surgery. Each patient is shown individually in upper two curves but in non-surgical group, which was larger, some points in descending part of curve (before 50 weeks) represent up to three patients.

resection ( $11 \%$ and $45 \%$ respectively). Whereas prognosis after extensive surgery approximated to that of stage A patients (see table I), after partial resection remission and survival rates were similar to those in the non-surgical group (14\% and $37 \%$ respectively). The differences in prolongation of remission and survival between the extensive and partial resection groups were statistically significant $(P<$ 0.001 and $P<0.05$ respectively; table III). These results were unlikely to be altered by funther follow-up of the patients since only one living patient in each group remained at significant risk of relapse having been in complete remission for less than one year.

The one patient in the extensive resection group who died had developed multiple cranial nerve palsies and paraplegia shortly after resection of bilateral ovarian tumours. She had a partial response to chemotherapy and died from staphylococcal septicaemia after receiving methotrexate. The outcome had she not died from septicaemia remains in doubt.

The close similarity between the extensive and partial resection groups (table IV) indicates that the difference in prognosis were due entirely to the surgical procedure. The non-surgical group contained more patients with extensive disease than did the other groups. There was a predominance of females in the surgical groups, and this is related to the high frequency (Magrath, 1974 a) and ease of resection of ovarian tumours. There was, however, no significant difference in remission and survival rates between males and females in the no-surgery group, and the similarity of prognosis between the partial resection (with an excess of females) and no-surgery groups further confirmed that sex was not a factor in the response to chemotherapy. Comparisons of different treatment subgroups in the partial resection and no surgery groups confirmed the lack of influence of the treatment regimen on prognosis (Ziegler, 1972).

\begin{tabular}{|c|c|c|c|c|c|}
\hline & & & $\begin{array}{l}\text { Extensive } \\
\text { Resection }\end{array}$ & $\begin{array}{c}\text { Partial } \\
\text { Resection }\end{array}$ & Non-surgical \\
\hline $\begin{array}{l}\text { No. of patients } \\
\text { Average age (yr) } \\
\text { Age range (yr) } \\
\text { Males: females }\end{array}$ & $\begin{array}{l}\cdots \\
\cdots \\
\cdots\end{array}$ & $\begin{array}{l}\ldots \\
\cdots \\
\ldots\end{array}$ & $\begin{array}{l}9 \\
6 \\
4-16 \\
2: 7\end{array}$ & $\begin{array}{c}16 \\
7 \cdot 5 \\
4-14 \\
2: 14\end{array}$ & $\begin{array}{c}43 \\
7.5 \\
3-60^{*} \\
21: 22\end{array}$ \\
\hline $\begin{array}{ccc}\text { Clinical } & \text { stage: } \\
\text { C } & \ldots & \ldots \\
& \ldots & \end{array}$ & $\because$. & 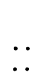 & $\begin{array}{l}7(78 \%) \\
2(22 \%)\end{array}$ & $\begin{array}{r}12(75 \%) \\
4(25 \%)\end{array}$ & $\begin{array}{l}20(46 \%) \\
23(54 \%)\end{array}$ \\
\hline $\begin{array}{l}\text { Therapy: } \\
\text { Cyclophosphamid } \\
\text { doses } \quad \therefore . \\
\text { Cyclophosphamid } \\
\text { TRIKE } \quad . .\end{array}$ & $\begin{array}{l}\text { or } 2 \\
\text { doses } \\
\cdots\end{array}$ & $\begin{array}{l}\cdots \\
\cdots\end{array}$ & $\begin{array}{l}6(67 \%) \\
3(33 \%) \\
0\end{array}$ & $\begin{array}{l}7(44 \%) \\
3(19 \%) \\
6(38 \%)\end{array}$ & $\begin{array}{r}14(33 \%) \\
21(49 \%) \\
8(18 \%)\end{array}$ \\
\hline
\end{tabular}

* One patient was aged 60 and one was aged 25 years but all the others were aged 15 TRIKE = Sequential combination of cyclophosphamide, vincristine, methotrexate, and cytosine arabinoside.

\section{BILATERAL OVARIAN TUMOURS}

The overall results did not differ when only females with bilateral ovarian tumours were considered (table V). All 10 patients who had unilateral oophorectomy relapsed, whereas only one in the bilateral oophorectomy group relapsed. Further, none of the living patients in the latter group remained at significant risk of relapse since all had been in remission for over 50 weeks. Survival was significantly longer in the bilateral oophorectomy group than in the unilateral oophorectomy group.

TABLB v-Statistical Comparison of Response to Chemotherapy after Removal of Both, One, or Neither of Bilaterally Affected Ovaries

\begin{tabular}{|c|c|c|c|c|c|c|c|c|c|c|c|c|c|}
\hline \multirow{2}{*}{$\begin{array}{c}\text { Surgical } \\
\text { Procedure }\end{array}$} & \multirow{2}{*}{$\begin{array}{l}\text { No. of } \\
\text { Patients }\end{array}$} & \multirow{2}{*}{$\begin{array}{c}\text { Survival } \\
\text { Rate }\end{array}$} & \multicolumn{2}{|c|}{ No. of Deaths } & \multirow{2}{*}{$\begin{array}{c}\text { Total } \\
\text { Patient- } \\
\text { Weeks of } \\
\text { Survival* }\end{array}$} & \multirow[t]{2}{*}{$x^{2}$} & \multirow[t]{2}{*}{$\mathbf{P}$} & \multirow{2}{*}{$\begin{array}{c}\text { Remission } \\
\text { Rate }\end{array}$} & \multicolumn{2}{|c|}{ No. of Relapses $\ddagger$} & \multirow{2}{*}{$\begin{array}{c}\text { Total } \\
\text { Patient- } \\
\text { Weeks of } \\
\text { Remission \& }\end{array}$} & \multirow[t]{2}{*}{$x^{2}$} & \multirow[t]{2}{*}{$\mathbf{P}$} \\
\hline & & & Observed & Expected & & & & & Observed & Expected & & & \\
\hline $\begin{array}{l}\text { Both } \\
\text { One } \\
\text { One } \\
\text { Neither } \\
\text { Both } \\
\text { Neither }\end{array}$ & $\begin{array}{r}6 \\
10 \\
10 \\
7 \\
6 \\
7\end{array}$ & $\begin{array}{l}83 \% \\
18 \% \\
18 \% \\
57 \% \\
83 \% \\
57 \%\end{array}$ & $\begin{array}{l}1 \\
7 \\
7 \\
3 \\
1 \\
3\end{array}$ & $\begin{array}{l}4.8 \\
3.2 \\
5.0 \\
5.0 \\
2.4 \\
1.6\end{array}$ & $\begin{array}{r}1,190 \\
785 \\
785 \\
782 \\
1,190 \\
782\end{array}$ & $\begin{array}{l}5.7 \\
0.89 \\
0.52\end{array}$ & $\left.\begin{array}{l}<0.025 \\
>0.3 \dagger \\
>0.4 \dagger\end{array}\right\}$ & $\begin{array}{r}83 \% \\
0 \% \\
0 \% \\
15 \% \\
83 \% \\
15 \%\end{array}$ & $\begin{array}{r}1 \\
10 \\
10 \\
6 \\
1 \\
6\end{array}$ & $\begin{array}{r}9.9 \\
1.1 \\
5.8 \\
10.2 \\
5.8 \\
1.2\end{array}$ & $\begin{array}{r}1,184 \\
138 \\
138 \\
245 \\
1,184 \\
245\end{array}$ & $\begin{array}{c}60.6 \\
3.7 \\
18.6\end{array}$ & $\begin{array}{l}<0.00001 \\
>0.05 \dagger \\
<0.0001\end{array}$ \\
\hline
\end{tabular}

* Sum of individual follow-up periods-either until death or until date last seen alive. 
For comparison a group of patients in whom bilateral ovarian tumour was the only clinically detectable intraabdominal tumour but in whom surgery was not undertaken is included in table V. Survival and remission were not significantly worse than in patients who had unilateral ovarian resection. Any differences, in fact, tended to favour the nosurgery group.

Patients with bilateral ovarian tumour in the no-surgery or partial resection group did not have any prognostic advantages over other patients in these groups.

\section{Discussion}

These results show that patients in whom intra-abdominal Burkitt's lymphoma was extensively resected had greatly improved prognosis, so that remission and survival rates after chemotherapy were similar to those of patients in whom abdominal tumour was never present. This was, however, a retrospective study and numbers were small, so that a degree of caution is indicated. Nonetheless, the differences in prognosis induced by extensive surgery, particularly in the proportion of patients that never relapse, are of sufficient magnitude to be most unlikely to be due entirely to chance. Imbalance between the surgical groups with regard to clinical stage, age, sex, and treatment was not present, and in any case the last three factors did not significantly influence prognosis in the non-surgical group. The possibility that the criterion of "fit for laparotomy" itself was of decisive importance is excluded by the closely similar remission and survival rates in the partial resection and no-surgery groups. Finally, the similarity of the overall findings in the $60 \%$ of patients in each surgical group who had bilateral ovarian involvement as their sole abdominal tumour, in whom the decision on extent of removal was effectively random, quantitation of resected tumour was very precise (removal of the largest or both ovaries), and potential differences in prognosis related to sex and variation in intra-abdominal tumour sites were excluded, lends strong support to the conclusion that extensive surgery results in a greatly improved prognosis.

It is reasonable to conclude that the response to chemotherapy depends primarily on the tumour volume at the start of drug treatment but that relatively large differences are necessary before significant differences in prognosis are detectable - that is, 90 to $99 \%$ or 10 - to 100 -fold (equivalent to one or two logarithm differences in cell number). This implies in turn that the clinical staging system, which was derived from the remission and survival rates, is basically a reflection of differences in tumour volume and that patients with stage $\mathrm{C}$ or $\mathrm{D}$ disease may be converted by surgery to stage $A$ or $B$.

\section{TREATMENT OF CHEMOTHERAPY-SENSITIVE TUMOURS}

The benefit of extensive surgery of Burkitt's lymphoma is in line with currently accepted concepts of the kinetics of chemotherapy (Skipper, 1970) and the role of host antitumour mechanisms (Klein, 1969; Ngu et al., 1970). In the case of tumours above a critical volume the amount of chemotherapy required to reduce tumour cell number to a level at which host defence mechanisms can control growth or destroy the residuum is often unacceptable in terms of toxicity and immunosuppression, so that cure is rarely achieved. Extensive surgery followed immediately by chemotherapy (thus preventing tumour regrowth which occurs between doses of drugs) may give rise to a situation in which an acceptable amount of chemotherapy in terms of immunosuppression is sufficient to reduce tumour volume to the level at which the host can cope with remaining cells. An additional advantage is that tumour-related immunosuppression, which has been described in a variety of animal (Linder, 1962; Matsuyana and Nakamura, 1964) and human tumours (Lamb et al., 1962; Robinson and Hochman, 1966), including Burkitt's lymphoma (Stjernsward et al., 1970; Magrath, 1974 b) is likely to be rapidly relieved, so that host immunological mechanisms are optimally effective.

If the experience with Burkitt's lymphoma is relevant to other tumour systems then the most dramatic improvements in results with large tumours are likely to be gained by emphasizing initial cytoreduction, utilizing all therapeutic modalities to their maximum extent, rather than prolonged intensive chemotherapy programmes which may have little chance of increasing the cure rate in tumours above a critical size.

Tumours in which this approach may be particularly valuable include lymphomas, choriocarcinoma, and some embryonal tumours, which are often highly sensitive to chemotherapy and amenable to extensive resection. Other means of bulk reduction should also be considered. Radiotherapy with its associated immunosuppression (Stjernsward et al., 1972) and often prolonged persistence of tumour antigen may or may not be equivalent to surgery, but cytophoresis by means of a cell centrifuge in leukaemias is worthy of study.

\section{DISADVANTAGES OF SURGERY}

In this series the surgical mortality rate was $10 \%$. Clearly, where extensive resection was achieved the risk was confined to that of the surgical procedure itself. The possibility of tumour dissemination when only partial resection is accomplished, however, must be considered, and this could explain the tendency for patients who had unilateral oophorectomy to have shorter remission duration and survival than patients with bilateral ovarian tumours treated by chemotherapy alone, though our figures do not permit a definite conclusion to be made.

A further consideration is the benefit of bilateral oophorectomy versus sterility and the necessity of hormonal replacement therapy. Our findings suggest that the chance of survival is approximately doubled by extensive resection. The disadvantages of castration depend to some extent on the environment. In Uganda tribal folk-lore and the difficulties of continued replacement therapy must be considered, as well as the feelings of the individual (if old enough to understand). Apart from rare, exceptional cases, however, most patients would probably wish to increase their chance of cure by every possible means.

We wish to express our gratitude to the physicians and surgeons who referred patients to the centre; Drs. J. L. Ziegler, A. Z. Bluming, and L. Fass and the surgical unit at Mulago Hospital, who helped in the clinical care of many of these patients; Mrs. Pamela Magrath, who retrieved much of the data; Dr. C. Vogel, who gave helpful advice on the preparation of the manuscript; and Mrs. Harriet Ssebambulidde and Mrs. M. Smith for secretarial work.

The Lymphoma Treatment Centre is jointly supported by contract PH 43-67-1343 of the National Cancer Institute, Bethesda, and Makerere University. One of us (I. T. Magrath) is in receipt of a grant from the Cancer Research Campaign (U.K.).

\section{References}

Fisher, B. (1972). Cancer, 30, 1556.

Klein, G (1969). Federation Proceedings, 28, 1739.

Lamb, D., Pilsney, F., Kelly, W. D., and Good, R. A. (1962). fournal of Immunology, 89, 555 .

Linder, O A .E. (1962). Cancer Research, 22, 380.

Magrath, I. T. (1974 b). Uganda Medical fournal. In press. 
Magrath, I. T. (1974 a) International fournal of Cancer. In press.
Magrath, I. $\dot{T}$., and Ziegler, J. L. (1973). In Uganda Cancer Institute, Annual Progress Report 1972-3. Kampala, Uganda.

Annual Progress Report 1972-3. Kampala, Uganda.
Matsuyana, M., and Nakamura, T. (1964). Nature, 202, 200.

Morrow, R. H., Pike, M. C., and Kisuule, A. (1967). British Medical Fournal, 4, 323.

Ngu, V. A., Burkitt, T. P., and Osunkoya, B. O. (1970). In Burkitt's Lymphoma, ed. D. P. Burkitt and D. H. Wright, p. 158. Edinburgh, Livingstone.

Nora, P. F., and Preston, F. W. (1963). Surgical Clinics of North America, 43, 39 .

Robinson, E., and Hochman, A. (1966). Fournal of the National Cancer Institute, 36, 819 .

Skipper, H. E. (1970). In Leukaemia-Lymphoma, 14th Annual Clinical Conference on Cancer, p. 27. Chicago, Year Book Medical Publishers.
Stjernsward, J., Clifford, P., and Svedmyer, E. (1970). In Burkitt's Lymphoma, ed. D. P. Burkitt, and D. H. Wright, p. 164. Edinburgh, Livingstone.

Stjernsward, J., Jondal, M., Vanky, F., Wigzell, H., and Sealy, R. (1972).

Lancet, 1, 1352 .
Wolff, J. A., Krivit, W., Newton, W. A., and D'Angio, G. J. (1968). New England fournal of Medicine, 279, 290.

Ziegler, J. L. (1972). Cancer, 30, 1534

Ziegler, J. L. and Bluming, A. Z. (1971). British Medical fournal, 3, 508.

Ziegler, J. L., Morrow, R. H., Fass, L., Kyalwazi, S. K., and Carbone, P. P. (1970). Cancer, 26, 474.

Ziegler, J. L., Bluming, A. Z., Fass, L., and Morrow, R. H. (1972 a). Cancer Research, 32, 1267.

Ziegler, J. L., Bluming, A. Z., Magrath, I. T., and Carbone, P. P. (1972 b). International fournal of Cancer, 10, 254.

\section{MEDICAL MEMORANDA}

\section{Meningioma Mimicking Features of a Phaeochromocytoma}

\author{
ROGER GABRIEL, B. D. W. HARRISON
}

British Medical fournal, 1974, 2, 312

We repont a case of a supratentorial meningioma in a patient who had episodic hypentension responsive to $\alpha$ - and $\beta$-blockade and associated with an excess urinary excretion of vanillomandelic acid (VMA). After excision of the tumour VMA excretion became normal.

\section{Case Report}

A 55-year-old woman was admitted through the casualty department, having been found lying in a street. She had experienced headache and vomiting and her employer volunteered symptoms suggestive of onganic confusion in the patient, but a detailed history was unobtainable.

On examination her weight was $69 \mathrm{~kg}$, and her blood pressure 195/120 mm Hg. She had complete right third nerve palsy and flaccid left hemiparesis. The results of skull and chest $x$-ray examinations and intravenous pyelography were normal. A lumbarpuncture showed clear fluid and a pressure of $270 \mathrm{~mm}$. E.E.G. showed right-sided abnormality. A right carotid angiogram showed a vascular tumour supplied by the middle œrebral artery in the region of the lesser wing of the right sphenoid bone, and a biopsy specimen of the tumour showed transitional cell meningioma.

During the days taken to complete these investigations her level of consciousness gradually deteriorated, and she did not respond to dexamethasone. After the excision of her meningioma the conscious level lightened for a few days but then relapsed and remained unchanged until her death.

Before the tumour was removed the patient remained hypertensive, and episodic increases of the hypertension to $215 / 150 \mathrm{~mm}$ $\mathrm{Hg}$ with tachycardia occurred. On the five occassions when 24hour urine specimens were assayed for VMA an excess was de-

Department of Nephrology, Hull Royal Infirmary, Hull, Humberside ROGER GABRIEL, M.sc., M.R.c.P., Renal Physician

Medical Unit, Westminster Hospital, London S.W.1 B. D. W. HARRISON, B.M., M.R.C.P., Medical Registrar tected (see table). The blood urea was in the normal range during the whole illness. The blood pressure evanescently responded to $10-\mathrm{mg}$, but not 5-mg, intravenous doses of phentolamine, and bo:h hypertension and tachycardia responded to $\beta$-blockade. After tumour excision the level of VMA excretion became normal, bu: the hypentension persisted.

The patient died of bronchopneumonia five months after admission. At necropsy much of the brain was seen to be infarc:ed. No residual tumour was present. No phaeochromocytoma was found in the abdomen or thorax.

\section{Discussion}

There is a linear relation between C.S.F. pressure and mean systemic arterial pressure in patients with cerebral tumours (Kety et al., 1948). Raised intracranial pressure can produce disturbances in vasomotor and respiratory function due to ischaemia of the medullary centres (Cushing, 1902; Eyster et al., 1909) with stimulation of the sympathoadrenal pathway. The resulting hypertension, due to catecholamine and perhaps renin release, can be blocked in dogs by spinal cord section or autonomic ganglion blockade by tetraethylammonium chloride (Dickinson and McCubbin, 1963). This is the only known pathway for neurogenic hypentension, and as cerebral tumours are common an excess of urinary VMA should be of ten found. It is therefore surprising that only one similar case has been previously reported (Evans et al., 1972). Cameron and Doig (1970) reponted two patients with infratentorial tumours who experienced marked phaeochromocytoma-like symptoms but who did not have excess VMA excretion

We report this case to emphasize the apparent infrequency of this association and to suggest that a prospective study would probably show further similar cases.

We thank Professor M. D. Milne for permission to report this case.

\section{References}

Cameron, S. J., and Doig, A. (1970). Lancet, 1, 492.

Cushing, H. (1902). American fournal of Medical Sciences, 124, 376

Dickinson, C. J., and McCubbin, J. W. (1963). Circulation Research, 12, 190 Evans, C. H., Westfall, V., and Atak, N. O. (1972). New England fournal of Medicine, 286, 1397.

Eyster, J. A. E., Burrows, M. T., and Essick, C. R. (1909). fournal of Experimental Medicine, 11, 489

Kety, S. S., Shenkin, H. A., and Schmidt, C. F. (1948). Journal of Clinical Investigation, 27, 493.

Excretion of Vanillomandelic Acid (VMA) in Patient with Meningioma

\begin{tabular}{|c|c|c|c|c|c|c|c|c|c|c|c|}
\hline $\begin{array}{l}\text { Date } \\
\text { VMA excretion }(\ddot{\mathrm{mg}} / 24 \ddot{\mathrm{hr}})\end{array}$ & $\because$ & $\because$ & $\begin{array}{l}14 / 9 / 72 \\
10.0\end{array}$ & $\begin{array}{l}26 / 9 / 72 \\
8 \cdot 6\end{array}$ & $\begin{array}{l}27 / 9 / 72 \\
9 \cdot 2\end{array}$ & $\begin{array}{l}2 / 10 / 72 \\
10 \cdot 7\end{array}$ & $\begin{array}{l}3 / 10 / 72 \\
10 \cdot 1\end{array}$ & $\begin{array}{l}\text { 9/10/72 } \\
\text { Tumour } \\
\text { Excision }\end{array}$ & $\underset{5 \cdot 1}{2 / 11 / 72}$ & $\begin{array}{l}4 / 11 / 72 \\
4 \cdot 6\end{array}$ & $27 / 11 / 72$ \\
\hline
\end{tabular}

Normal $=<7 \mathrm{mg} / 24 \mathrm{hr}$. 